\title{
PROFESSIONAL COMPETENCIES OF EMPLOYEES IN TOURISM SECTOR IN POLAND
}

\author{
A. Wartecka-Ważyńska \\ Akademia Wychowania Fizycznego im. Eugeniusza Piaseckiego w Poznaniu \\ Poznań, Poland
}

\begin{abstract}
Universities of physical education train specialists at the study majors of physical education, physical therapy, tourism and recreation, sport etc. The graduates from these universities are prepared to work in the education sector, sports club, health centres, travel agencies, hotels etc. Throughout the university course, they acquire a number of professional competencies. The paper emphasizes the professional competencies of the graduates from tourism and recreation courses which are used in the labour market. Material and Methods. The study covered 229 graduates from the University School of Physical Education in Poznań, Poland, including 101 people from tourism and recreation study major. The study was carried out within the time frame of 2007-2010. The study used a statistical method and the method of opinion poll using an internet survey. Furthermore, the author carried out a literature survey and used the results of her own observations and experience connected with teaching students at the University School of Physical Education in Poznań at the Faculty of Tourism and Recreation. Results. The study demonstrated that the graduates from the study major of tourism and recreation appreciated their practical and professional preparation very high, including preparation for managing people. Conclusions. The respondents who graduated from the University School of Physical Education in Poznan at the study major of tourism and education answered that they have suitable qualifications and professional competencies for working in the tourism sector i.e. in travel agencies, hotels and tourist information centres.
\end{abstract}

Keywords: graduates, competencies, employment, labour market

\section{Introduction}

Development of human resources in an organization can be defined as a process of supplementation of knowledge and improvement of skills and competencies required for proper performance of tasks in actual workplaces and acquisition of the abilities that are conducive to development of knowledge and professionals aimed at promotion, shift or organizational changes [1]. Professional competencies are viewed as aptitudes in terms of knowledge, skills and attitudes which allow for achievement of professional goals at a specific level [1].

The universities of physical education usually teach students at the following study majors: physical education, tourism and recreation, sport, physical therapy, cosmetology and nursing. Their graduates are employed in the education sector, health centres, recreation and sport centres, sport clubs, travel agencies etc.

The aim of the study was to determine the scope of competencies obtained by the graduates from the study major of tourism and recreation at the University School of Physical Education within the time frame of 2007-2010.

(C) Wartecka-Ważyńska A., 2013 
Apart from the universities of physical education in Poland, there is a variety of those specialized for the tourism sector. These are both public and private entities that educate at the level of secondary, post-secondary, higher vocational, tertiary and post-graduate studies.

The nineties of the 20th century saw a rapid increase in a variety of forms of education in tourism. Almost 10-time increase in the number of secondary schools and three-time increase in the number of tourism universities was observed in 1992-2000.

In 2002/2003 school year, eight thousand students completed secondary schools and post-secondary tourism and hotel-management schools, whereas 7,000 people graduated from universities with this profile. There is a surplus of tourism graduates in the labour market where employers define the conditions of work and salary level. There were 4,188 people who graduated from universities with tourism profile in 2001/2002 school year and 4,337 of graduates in 2002/2003. After accession of Poland to the EU, a rapid rise in the number of graduates from the study major of tourism and recreation was observed.

There were 13,365 graduates who were professionally prepared to provide services in the tourism sector in 2009. This was an increase by 43\% compared to the year 2006 [2].

At the level of higher education, all the possible forms of education should be present i.e. bachelor's, master's and post-graduate courses. The level of qualifications and innovativeness of the employed determines the economic growth in tourism sector and improvement in the level of tourist services. Working in the tourism sector necessitates not only knowledge, experience, organizational skills or ability to speak languages (and other professional skills), but also inventiveness or flexibility to variable conditions in the tourist market [2]. Development and education of human resources in an organization can be defined as a process of supplementation of knowledge, developing their skills and competencies which are necessary for proper performance of tasks at actual workplaces and providing opportunities for additional development of knowledge and competencies in terms of promotion, shift or organizational changes [1].

\section{Material and Method}

The studies concerning the graduates from universities are carried out by means of a variety of methods and research techniques. The most popular include regular mail questionnaire, auditory methods, questionnaires sent via e-mail or a questionnaire placed at the websites owned by the universities. Different questionnaire-based techniques are included in the method of opinion poll survey. The present study used the method of diagnostic survey based on a technique of Internet questionnaire. The statistics were supposed to point to certain correlations and distributions. In order to measure the relationships between the variables, the author used a C-Pearson's contingency coefficient based on $\chi^{2}$, which determines the strength of the relationship between two variables and using V-Cramer coefficient as an alternative for C-Pearson's contingency coefficient. Moreover, the author also used correspondence analysis, which allows for presentation, in a low-dimensional space (typically two-dimensional), of the characteristics typical of the object studies and the dimensions which differentiate the set of objects the most. This allows the data collected to be transparent, which facilitates their further interpretation.

The questionnaire surveys are a specific, formalized and written form of interview. 
Nowadays, it is among the most common and even overused research techniques. There are the following types of questionnaire surveys:

- by mail: the method of collecting data without an interviewer. Under some conditions and for particular research purposes, it might turn to be useful [3].

- in newspapers: the questionnaire is published in a newspaper or journal and returned by mail,

- in the radio: the text of the questions is broadcast through the radio, whereas the responses are returned by mail,

- by telephone: the text of the questionnaire is telephoned to the respondent and the answer is returned by mail [4].

- auditory: it consists in collecting in a particular space, usually in a room, a group of randomly selected people and distribution of the questionnaires to fill in [5].

- via Internet: a questionnaire is published in the Internet. Ever-growing access to the global networks causes that this medium is becoming an important method for socioeconomic and marketing research.

The Internet survey is economical, which means that the use of the Internet shortens the time to reach a respondent and collect the data. It also shortens the time for data analysis since there is no necessity of transcription of the interviews, manual coding of answers etc. Another advantage of Internet surveys include financial savings on printing questionnaires, training and salaries for interviewers or coding and statistical processing of the material collected [6].

The investigations for the purposes of this paper were carried out at three stages:

Stage I means development of survey methodology, creation of survey questionnaire, databases, literature studies, observations

Stage II involves implementation of the research, collecting answers, coding and analysis of the data, conclusion and promotion of the research.

Stage III focuses on popularization of the results of the survey at national and international conferences, meetings with experts in similar domains of science and publications in scientific journals.

The questionnaire used in this study was presented in the webpage of the University School of Physical Education in Poznań in 2007-2011 and it analysed a group of 229 graduates from this university.

The characteristics of the population of the graduates included such characteristics as gender, place of residence, study major (Tables 1, 2, 3, 4), sector a graduate is employed in and financial situation.

Considering gender, it turns out that women accounted for $52 \%$ and men were $48 \%$ of the whole population of the graduates. With respect to the study major, there were $44 \%$ of the graduates ( $56 \%$ of women and $44 \%$ of men) who graduated from tourism and recreation, physical education $-42 \%$ ( $43 \%$ of women and $57 \%$ of men), physical therapy $-14 \%$ (68\% of women and $32 \%$ of men) (see Tab. 1$)$. 
Table 1. Characteristics of the respondents due to gender and the study major they graduated from

\begin{tabular}{|l|l|l|l|l|l|l|l|l|}
\hline \multirow{2}{*}{ Gender } & \multicolumn{2}{|c|}{ Total } & \multicolumn{6}{c|}{ Study Major } \\
\cline { 4 - 10 } & \multicolumn{3}{|c|}{} & \multicolumn{2}{c|}{$\begin{array}{c}\text { Tourism and } \\
\text { Recreation }\end{array}$} & \multicolumn{2}{c|}{ Physical Education } & \multicolumn{2}{c|}{ Physical Therapy } \\
\cline { 2 - 9 } & $\mathrm{N}$ & $\%$ & $\mathrm{~N}$ & $(\%)$ & $\mathrm{N}$ & $(\%)$ & $\mathrm{N}$ & $(\%)$ \\
\hline Women & 119 & 52.00 & 56 & 56.00 & 42 & 43.00 & 21 & 68.00 \\
\hline Men & 110 & 48.00 & 45 & 44.00 & 55 & 57.00 & 10 & 32.00 \\
\hline Total & 229 & 100.00 & 101 & 100.00 & 97 & 100.00 & 31 & 100.00 \\
\hline
\end{tabular}

Source: authors own elaboration

Comparing the structure of gender among the graduates and the study major they graduated from, one can observe that the study major of tourism and recreation and physical therapy was dominated by women ( $56 \%$ and $68 \%$, respectively), whereas the major of physical education was dominated by men (57\%). These data lead to the conclusion that the graduates from the university school of physical education are mainly women.

Considering the place of residence, the graduates are mainly people who live in the cities $(81 \%)$, whereas $19 \%$ of the respondents lived in the rural areas. The greatest number of respondents lived in bigger cities of over 101,000 of inhabitants (31\%) (Fig. 2).

Table 2. Place of residence

\begin{tabular}{|l|l|l|l|}
\hline No. & Place of Residence & Number & Percentage \\
\hline 1. & Rural areas & 43 & 18.80 \\
\hline 2. & Town up to 25 thousand inhabitants & 47 & 20.50 \\
\hline 3. & City with 26-50 thousand inhabitants & 26 & 11.40 \\
\hline 4. & City with 50-100 thousand inhabitants & 42 & 18.30 \\
\hline 5. & City with 101 thousand inhabitants and more & 71 & 31.00 \\
\hline & Total & 229 & 100.00 \\
\hline
\end{tabular}

Source: authors own elaboration

Table 3. Graduates from the University School of Physical Education in Poznań in 2007-2010 according to the study major

\begin{tabular}{|l|c|c|c|c|c|c|c|c|}
\hline \multirow{2}{*}{ Study Major } & \multicolumn{7}{|c|}{ Number of Graduates per Year } \\
\cline { 2 - 10 } & 2007 & $\%$ & 2008 & $\%$ & 2009 & $\%$ & 2010 & $\%$ \\
\hline Physical Therapy & 146 & 15.00 & 95 & 14.00 & 442 & 27.00 & 403 & 25.00 \\
\hline $\begin{array}{l}\text { Tourism and } \\
\text { Recreation }\end{array}$ & 268 & 29.00 & 242 & 35.00 & 703 & 43.00 & 485 & 30.00 \\
\hline Physical Education & 526 & 56.00 & 354 & 51.00 & 482 & 30.00 & 722 & 45.00 \\
\hline Total & 940 & 100.00 & 691 & 100.00 & 1627 & 100.00 & 1610 & 100.00 \\
\hline
\end{tabular}

Source: data obtained from Poviat Labour Office in Poznań, www.pup.poznan.pl

At the end of the characterization of the research material, one should emphasize that the graduates are a representative population with respect to all the graduates of physiotherapy, tourism and recreation and physical education who completed the 
University School of Physical Education in Poznań in 2007-2010. This view is supported by the comparative data contained in Tables 3,4 and 5 .

In order to verify the representativeness of the research sample, the author carried out calculations to compare populations of all the graduates from the University School of Physical Education in Poznan for the three study majors for selected sample of the graduates in consideration of gender, study major in 2007-2010

Table 4. Comparison of the population of the graduates from the University School of Physical Education in Poznań with the research sample with respect to gender and study major $(\%)$

\begin{tabular}{|c|c|c|c|}
\hline Characteristic & \multirow[t]{2}{*}{ Sample $\left(\mathrm{f}_{\mathrm{o}}\right)$} & \multirow[t]{2}{*}{ Population $\left(f_{e}\right)$} & \multirow[t]{2}{*}{$\left(f_{o}-f_{e}\right)^{2} / f_{o}$} \\
\hline Gender & & & \\
\hline Women & 52.00 & 55.00 & 1.7 \\
\hline Men & 48.00 & 45.00 & 1.8 \\
\hline Total & 100.00 & 100.00 & 3.5 \\
\hline \multicolumn{4}{|l|}{ Study Major } \\
\hline Physical Education & 42.30 & 45.40 & 0.2 \\
\hline $\begin{array}{l}\text { Tourism and } \\
\text { Recreation }\end{array}$ & 44.10 & 34.20 & 2.2 \\
\hline Physical Therapy & 13.60 & 20.40 & 3.4 \\
\hline Total & 100.00 & 100.00 & 5.87 \\
\hline
\end{tabular}

Source: data based on Table 1 and 3

Table 5. Statistical consistency of distributions of the research sample with respect to gender and study major

\begin{tabular}{|l|l|c|l|l|}
\hline Specification & $\begin{array}{l}\text { Number of Degrees } \\
\text { of Freedom }\end{array}$ & Empirical Value c $c^{2}$ & $\begin{array}{l}\text { Critical Value c } \\
(\mathrm{a}=0.05)\end{array}$ & $\begin{array}{l}\text { Statistical } \\
\text { Consistency of } \\
\text { Distribution }\end{array}$ \\
\hline Gender & 1 & 3.5 & 4.8 & Yes \\
\hline Study Major & 2 & 5.8 & 6.0 & Yes \\
\hline
\end{tabular}

Source: authors own elaboration

Verification of the representativeness of the survey in terms of distribution of research population and sample carried out by chi-squared test allowed for finding that the structure of the sample corresponds in terms of gender and study major to the structure of population.

\section{Results}

\section{Professional competencies of graduates}

When analysing the results of empirical studies concerning professional competencies of the graduates from the universities of physical education, it should be noted that they are a significant factor in development of human resources in each organization.

The aim of development of human resources is to provide organizations with employees who are not only properly educated by they also have specific personality traits, professional 
knowledge and skills which are necessary to achieve the business goal (e.g. increase, growth, improved efficiency) [1].

The scope of professional competencies was presented by Szempruch, who pointed to the following competencies: interpretational and communicational competencies (ability to understand and define situations at work, effectiveness of communicational verbal and non-verbal behaviours); creative competencies (innovativeness and prodevelopment effectiveness of actions); cooperative competencies (effectiveness of social behaviours and efficiency of integration of employee teams); pragmatic competencies (effectiveness of planning, organizing, motivating, achievement and evaluation of the processes of professional work); information and media-related competencies (ability to utilize information and communication technology in improvement of work [1].

In the present study, professional competencies of the graduates from the university schools of physical education were restricted to: practical-professional preparation, preparation for educational work, preparation for managing people and organizationalmanagerial preparation. These competencies will be related to the three study majors of education in the University School of Physical Education in Poznan i.e. physical education, tourism and recreation and physical therapy. A particular focus was on professional competencies of the graduates in the study major of tourism and recreation.

\subsection{Practical and Professional Preparation}

Selected directions of education in universities of physical education are commonly considered as very interesting due to a high share of attractive physical activities, although in fact they are not easy study majors. The curricula encompass a wide area of knowledge in such fields as pedagogy, biomedicine (or medicine in the case of physical education), theory of sport, recreation, philosophy, sociology, organization and management of human resources, organization and methods of scientific research as well as other contents and skills realized autonomously by individual universities. An important feature of the students in the universities of physical education is interests and motor aptitudes, with particular focus on health which is fundamental for successful graduation [7].

According to the demands of the practice, the universities of physical education adopted a profile of a 'universal graduate' who is able to independently define the problems, solve them skilfully, and perform the role of both organizer and performer of the tasks. The example of this approach to education is the educational process in the study major of tourism and recreation which assumes that a graduate with a master's degree in tourism and recreation should acquire skills and competencies in the field of e.g. history of culture, sociology of leisure time, tourist regions, information technology in tourism and recreation, marketing of tourist and recreational services, enterprise management etc. Therefore, the graduates acquire theoretical and practical skills which play an important role in providing tourist and recreational services in hotels, recreation centres, travel agencies etc.

The study also demonstrated that graduation from the University School of Physical Education allowed the graduates to acquire adequate practical and professional preparation as an important element of professional competencies. This was confirmed by positive answers obtained from the graduates of physical education (90\%), tourism and recreation $(60 \%)$ and physical therapy $(74 \%)$ (Table 6). 
Table 6. Professional competencies of graduates from the University School of Physical Education in Poznań with respect to study major

\begin{tabular}{|l|c|c|c|c|c|c|c|c|c|c|c|c|c|}
\hline \multirow{2}{*}{$\begin{array}{l}\text { Professional } \\
\text { Competencies }\end{array}$} & \multicolumn{10}{|c|}{ Physical Education } & \multicolumn{10}{|c|}{ Tourism and Recreation } & \multicolumn{3}{|c|}{ Physical Therapy } & Total \\
\cline { 2 - 12 } & Yes & $\%$ & No & $\%$ & Yes & $\%$ & No & $\%$ & Yes & $\%$ & No & $\%$ & \\
\hline $\begin{array}{l}\text { Practical and } \\
\text { Professional } \\
\text { Preparation }\end{array}$ & 87 & 90.00 & 10 & 10.00 & 61 & 60.00 & 40 & 40.00 & 23 & 74.00 & 8 & 26.00 & 229 \\
\hline $\begin{array}{l}\text { Preparation } \\
\text { for } \\
\text { Educational } \\
\text { Work }\end{array}$ & 68 & 70.00 & 29 & 30.00 & 55 & 54.50 & 46 & 45.50 & 15 & 48.00 & 16 & 52.00 & 229 \\
\hline $\begin{array}{l}\text { Preparation } \\
\text { for Managing } \\
\text { People }\end{array}$ & 58 & 60.00 & 39 & 40.00 & 48 & 48.00 & 53 & 52.00 & 11 & 35.50 & 20 & 64.50 & 229 \\
\hline $\begin{array}{l}\text { Managerial } \\
\text { and } \\
\begin{array}{l}\text { Organizational } \\
\text { Preparation }\end{array}\end{array}$ & 43 & 44.00 & 54 & 46.00 & 60 & 59.00 & 41 & 41.00 & 6 & 19.00 & 25 & 81.00 & 229 \\
\hline
\end{tabular}

Source: authors own elaboration

*The respondents were allowed to provide more than one answer. Therefore, the percentage values do not total to $100 \%$

Graduation from the university with an adequate scope of professional competencies opens up the opportunities to use them at work.

As results from the answers given by the graduates from the University School of Physical Education in Poznań, the most of them were professionally active, $48 \%$ of the respondents started working in Poland based on a contract of permanent employment, $20 \%$ of them worked and learned on, $10 \%$ of the graduates found jobs abroad, $4 \%$ were self-employed and other $4 \%$ started learning at another university major. Considering the percentage of the unemployed graduates (lack of employment, does not work), the professional activity was a dominant form in the labour market among the graduates (Table 7).

Table 7. Professional activity of graduates from the University School of Physical Education in Poznań according to the study major

\begin{tabular}{|l|l|l|l|l|l|l|l|l|}
\hline \multirow{2}{*}{$\begin{array}{l}\text { Professional } \\
\text { Activity }\end{array}$} & \multicolumn{3}{|c|}{ Total } & \multicolumn{6}{c|}{ Study Major } \\
\cline { 3 - 9 } & \multicolumn{2}{|c|}{$\begin{array}{l}\text { P h y s i c a I } \\
\text { Education }\end{array}$} & $\begin{array}{l}\text { Tourism and } \\
\text { Recreation }\end{array}$ & \multicolumn{2}{c|}{ Physical Therapy } \\
\cline { 2 - 9 } & $\mathrm{N}$ & $\%$ & $\mathrm{~N}$ & $\%$ & $\mathrm{~N}$ & $\%$ & $\mathrm{~N}$ & $\%$ \\
\hline $\begin{array}{l}\text { working in } \\
\begin{array}{l}\text { Poland based on a } \\
\text { permanent contract } \\
\text { of employment }\end{array}\end{array}$ & 109 & 48.00 & 60 & 60.00 & 40 & 40.00 & 9 & 30.00 \\
\hline $\begin{array}{l}\text { employed and } \\
\text { continues learning }\end{array}$ & 45 & 20.00 & 18 & 19.00 & 19 & 19.00 & 8 & 26.00 \\
\hline Working abroad & 22 & 10.00 & 4 & 4.00 & 11 & 11.00 & 7 & 23.00 \\
\hline
\end{tabular}




\begin{tabular}{|l|l|l|l|l|l|l|l|l|}
\hline $\begin{array}{l}\text { set up their own } \\
\text { business }\end{array}$ & 12 & 4.00 & 3 & 3.00 & 5 & 5.00 & 4 & 13.00 \\
\hline $\begin{array}{l}\text { started education } \\
\text { at another study } \\
\text { major }\end{array}$ & 10 & 4.00 & 3 & 3.00 & 6 & 6.00 & 1 & 3.00 \\
\hline Other & 31 & 14.00 & 9 & 9.00 & 20 & 20.00 & 2 & 7.00 \\
\hline Total & 229 & 100.00 & 97 & 42.00 & 101 & 44.00 & 31 & 14.00 \\
\hline
\end{tabular}

Source: authors own elaboration

Contingency coefficient $=0.329$

The interesting relationships can be demonstrated between the workplace and the study major a person graduated from (Fig. 1).

(inne-other, dalsze kształcenie - post-graduate education, turystyka in rekreacja tourism and recreation, w kraju, umowa o prace - in Poland, contract of employment, praca i dalsze kształcenie - working and post-graduate education, wychowanie fizyczne - physical education, praca za granicą - working abroad, własna działaność gosp. - self-employed, fizjoterapia - physical therapy)

- - study major

- - professional activity

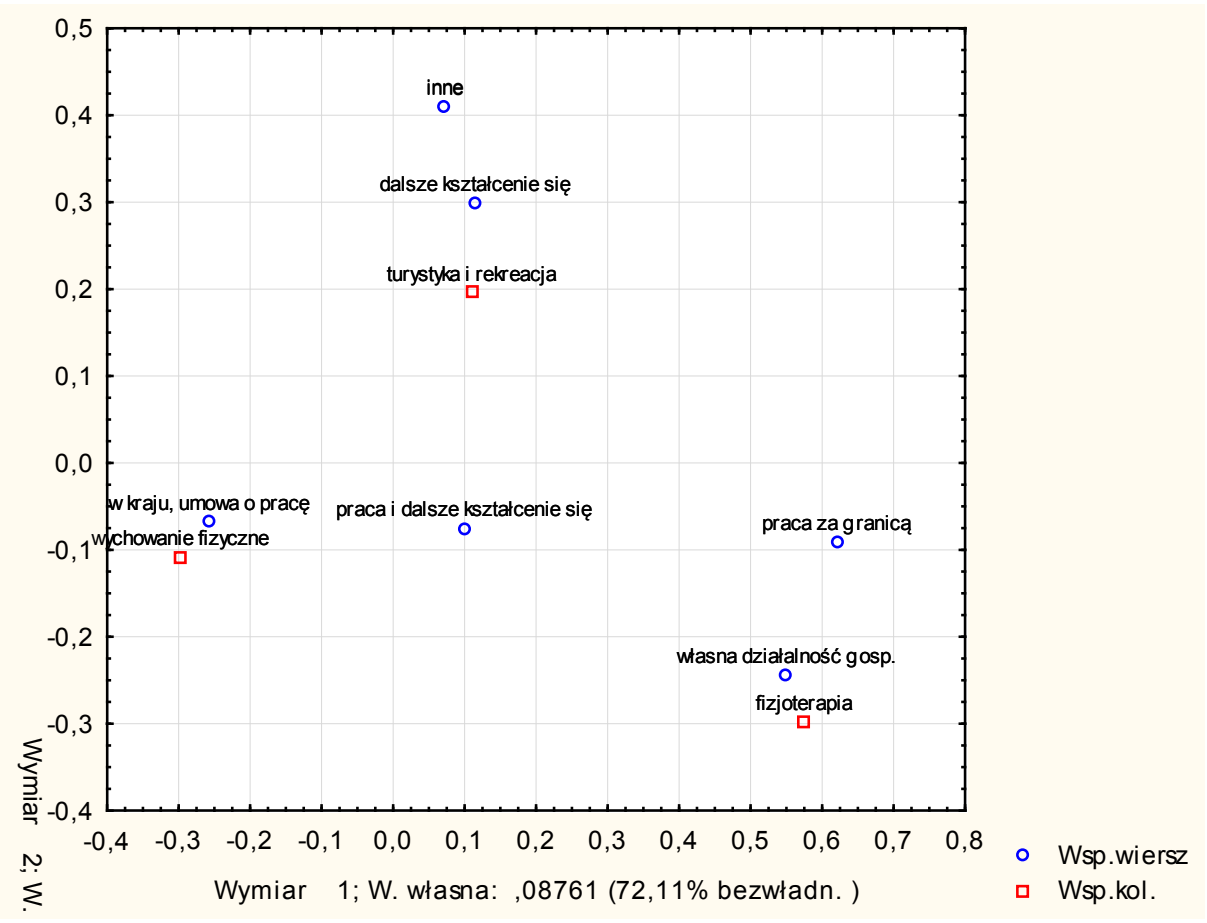

Fig. 1. Places of professional work of the graduates from the University School of Physical Education in Poznań vs. study major

Source: authors own elaboration 
The figure which presents the profiles of rows and columns corresponding to the workplace and study major of the respondents points unequivocally to presence of relationships between the variables. It can be concluded that the people who graduated from the major of physical education work, more often than the graduates from other majors, on employment contract basis at work as physical education teachers. The graduates who studied physical therapy are more often self-employed and work abroad. The centres of physical therapy and private surgeries of athletic recovery employ physical therapists on mandatory agreement basis or are self-employed. Furthermore, the graduates from tourism and recreation, compared to the graduates from the above majors, learn at post-graduate courses which allows them to acquire additional qualifications and authorizations e.g. courses in tour guides necessary to work in travel agencies, hotels etc.

Professional activities performed in suitable workplaces has essential practical dimension, which is increasingly appreciated by the employees. Therefore, the contents of tertiary education reforms addressed this problem. This means that the process of education at the level of university should be structured so that a graduate leaves the school with particular skills in terms of time management, working in teams, working with customers, speaking foreign languages and interpersonal communication.

Institutions of the tourism sector, physical therapy and education which employ the graduates from the universities of physical education emphasize deficiency of the above skills.

Graduating from a university cannot be restricted to a particular level and scope of knowledge used in practice, but it also involves broader opportunities of managerial positions and thus using the skills of managing human teams.

\subsection{Preparation for managing people}

Human resource management is a strategic and consistent approach to managing the most valuable assets in each organization i.e. the people, who, either individually or as a group, contribute to achievement of the organization's goals [8].

The graduates from the University School of Physical Education in Poznań emphasized that the university provided them with suitable professional competencies. Practical and professional preparation was mentioned by $88 \%$ of the graduates, preparation for educational work $-88 \%$, ability of managing people $-78 \%$, organizational and managerial skills $45 \%$. As can be concluded from the present study, the graduates from this university are prepared to manage people. These competencies are used in education (teacher - student), travel agencies and hotels (manager-customer) or sports clubs (coach-athletes).

Table 8. Preparation for managing people and the study major

\begin{tabular}{|c|c|c|c|c|c|c|}
\hline Professional & \multicolumn{6}{|c|}{ Study Major } \\
\cline { 2 - 7 } $\begin{array}{c}\text { Competencies - } \\
\text { Preparation for } \\
\text { Managing People }\end{array}$ & \multicolumn{2}{|c|}{ Physical Education } & \multicolumn{2}{c|}{ Tourism and Education } & \multicolumn{2}{c|}{ Physical Therapy } \\
\cline { 2 - 7 } & $\mathrm{N}$ & $\%$ & $\mathrm{~N}$ & $\%$ & $\mathrm{~N}$ & $\%$ \\
\hline Yes & 58 & 59.8 & 48 & 47.5 & 11 & 35.5 \\
\hline No & 39 & 40.2 & 53 & 52.5 & 20 & 64.5 \\
\hline Total & 97 & 42.4 & 101 & 44.1 & 31 & 13.5 \\
\hline
\end{tabular}

Source: authors own elaboration

Contingency coefficient $=0.165$ 
Preparation for managing groups of employees was emphasized among the graduates of the study major of physical education by ca. $60 \%$ of the respondents, among tourism and recreation graduates $-47.5 \%$, physical therapists - only $35.5 \%$. The latter result is not optimistic. It is likely that the curricula should be extended over the subjects which focus on these competencies (Table 8).

It is also essential to compare the competencies in the field of managing people with the sector of graduate employment (Tab. 9). The graduates from the major of physical education declared that they are prepared to managing people. The usually started jobs in education (61.2\%) and sport clubs (54.3\%) and emphasized that the university prepared them for working in this profession very well. The graduates from the major of tourism and recreation evaluated preparation for managing people in their profession as very high $(47.5 \%)$. They started jobs in hotel management, tourism and recreation as hotel managers and managers in travel agencies. The competencies of managing people are in their case essential, whereas the graduates of the major of physical therapy emphasized their preparation to managing people to lower extent $(35.5 \%)$. They are employed in health centres as physical therapists, therefore, the skills of preparation for managing people is not as much demanded in this job. Nevertheless, when they are promoted and take managerial positions, the problem might turn out to be important.

Table 9. Preparation for managing people and employment sector

\begin{tabular}{|c|c|c|c|c|c|c|c|c|c|c|}
\hline \multirow{3}{*}{$\begin{array}{c}\text { Preparation } \\
\text { for } \\
\text { Managing } \\
\text { People }\end{array}$} & \multicolumn{10}{|c|}{ Employment Sector } \\
\hline & \multicolumn{2}{|c|}{ Education } & \multicolumn{2}{|c|}{$\begin{array}{c}\text { Hotel } \\
\text { Management }\end{array}$} & \multicolumn{2}{|c|}{$\begin{array}{c}\text { Sport and } \\
\text { Physical Culture }\end{array}$} & \multicolumn{2}{|c|}{$\begin{array}{l}\text { Tourism and } \\
\text { Recreation }\end{array}$} & \multicolumn{2}{|c|}{ Health Centres } \\
\hline & $\mathrm{N}$ & $\%$ & $\mathrm{~N}$ & $\%$ & $\mathrm{~N}$ & $\%$ & $\mathrm{~N}$ & $\%$ & $\mathrm{~N}$ & $\%$ \\
\hline Yes & 41 & 61.2 & 6 & 50.0 & 25 & 54.3 & 20 & 48.8 & 25 & 39.7 \\
\hline No & 26 & 38.8 & 6 & 50.0 & 21 & 45.7 & 21 & 51.2 & 38 & 60.3 \\
\hline Total & 67 & 29.3 & 12 & 5.2 & 46 & 20.1 & 41 & 17.9 & 63 & 27.5 \\
\hline
\end{tabular}

Source: authors own elaboration

\section{Conclusions}

The results of the study contributed indirectly to the achievement of the goal set for the paper and thus they provided direct information about professional competencies and their importance to the practice expressed by the graduates from the University School of Physical Education, with particular focus on the major of tourism and recreation. It allowed for formulation of several cognitive conclusions:

1. The graduates from the major of tourism and recreation assessed their professional competencies in terms of organizational and managerial abilities and managing people as high.

2. The opinion of the graduates is that their professional preparation matches the variable demands of the labour market.

3. The graduates of the major of tourism and recreation expressed their opinion that the professional competencies acquired during the study at the university can be successfully used at work which is consistent with the study major, which is tourist market in this case. 


\section{LIST OF REFERENCES}

1. Hołderna-Mielcarek B., Wartecka-Ważyńska A. (2010) Kompetencje zawodowe i ich znaczenie we współczesnym przedsiębiorstwie turystycznym. [w]: S. Tanaś (ed.) Nauka i dydaktyka w turystyce i rekreacji. Łódzkie Towarzystwo Naukowe. Łódź

2. Borne-Januła H., Banach Wt., Stan edukacji w Polsce w stosunku do potrzeb gospodarki turystycznej, w: Gospodarka turystyczna w regionie. Przedsiębiorstwo. Samorząd. Współpraca, ed. A. Rapacz, Wyd. Uniwersytetu Ekonomicznego we Wrocławiu, Wrocław 2010

3. Frankfort-Nachmias Ch., Nachmias D. (2007) Metody badawcze w naukach społecznych. Poznań: Zysk i S-ka

4. Lutyński J. (2000) Metody badań społecznych. Wybrane zagadnienia. Łódź: Komitet Badań Naukowych i Urzędu Miasta Łodzi

5. Szczurkiewicz T. (1970) Niektóre uwagi krytyczne o ankietach, [in:] tegoż autora, Studia socjologiczne. Warszawa: PWN

6. Sikora J. (2010) Ankieta internetowa w badaniach ekonomiczno-socjologicznych. [in:]: A. Grzelak, K. Pająk (ed.) Nowe trendy w metodologii nauk ekonomicznych, ed. Wyd. UE w Poznaniu. Poznań

7. Szczepański S. (2004) Determinanty wyboru studiów na Wydziale Wychowania Fizycznego i Fizjoterapii. Opole: Politechnika Opolska

8. Armstrong M. (2002) Zarządzanie zasobami ludzkimi. Kraków: Oficyna Ekonomiczna

Стаття: надійшла до редколегї 06.06.2012

прийнята до друку 15.06.2012 


\title{
ПРОФЕСІЙНА КОМПЕТЕНЦІЯ ПРАЦІВНИКІВ ГАЛУЗІ ТУРИЗМУ В ПОЛЬЩІ
}

\author{
А. Вартецька-Важинська \\ Академія фізичного виховання ім. Свгенія П'ясецького в Познані \\ Познань, Польща
}

Університети фізичної освіти готують фахівців в дослідженні фізичного виховання, фізичної терапії, туризму і відпочиноку, спорту і т.д. Випускники цих вузів готові працювати в сфері освіти, спортивних клубах, медичних центрах, туристичних агентствах, готелях i т.д. Протягом всього курсу університету, вони здобувають ряд професійних компетенцій. У документі підкреслюється професійні компетенції випускників в галузі туризму та відпочинку.

Ключові слова: випускники, компетенція, зайнятість, ринок праці, туризм, відпочинок.

\section{ПРОФЕССИОНАЛЬНАЯ КОМПЕТЕНЦИЯ РАБОТНИКОВ ОТРАСЛИ ТУРИЗМА В ПОЛЬШЕ}

\author{
А. Вартецкая-Важинская \\ Академия физического воспитания им. Евгения Пясецкого в Познани \\ Познань, Польша
}

Университеты физического образования готовят специалистов в исследовании физического воспитания, физической терапии, туризма и отдыхе, спорта и т.д. Выпускники этих вузов готовы работать в сфере образования, спортивных клубах, медицинских центрах, туристических агентствах, отелях и т.д. На протяжении всего курса университета, они приобретают ряд профессиональных компетенций. В документе подчеркивается профессиональные компетенции выпускников в области туризма и отдыха.

Ключевые слова: выпускники, компетенция, занятость, рынок труда, туризм, отдых. 